\title{
Use of radium isotopes to estimate mixing rates and trace sediment inputs to surface waters in northern Marguerite Bay, Antarctic Peninsula
}

\author{
AMBER L. ANNETT ${ }^{1}$, SIAN F. HENLEY ${ }^{1}$, PIETER VAN BEEK ${ }^{2}$, MARC SOUHAUT ${ }^{2}$, RAJA GANESHRAM ${ }^{1}$, \\ HUGH J. VENABLES ${ }^{3}$, MICHAEL P. MEREDITH ${ }^{3}$ and WALTER GEIBERT ${ }^{1,4}$ \\ ${ }^{I}$ School of GeoSciences, University of Edinburgh, Edinburgh EH9 3JW, UK \\ ${ }^{2}$ Laboratoire d'Etudes en Geophysique et Oceanographie Spatiales (CNRS/UPS/IRD/CNES), \\ Observatoire Midi Pyrénées, Toulouse, France \\ ${ }^{3}$ British Antarctic Survey, NERC, High Cross, Madingley Road, Cambridge CB3 OET, UK \\ ${ }^{4}$ Scottish Association for Marine Science (SAMS), Scottish Marine Institute, Oban, UK \\ amber.annett@ed.ac.uk
}

\begin{abstract}
In the western Antarctic Peninsula region, micronutrient injection facilitates strong plankton blooms that support productive food webs, unlike large areas of the low-productivity Southern Ocean. We use naturally occurring radioisotopes of radium to constrain rates of chemical fluxes into Ryder Bay (a small coastal embayment in northern Marguerite Bay), and hence to evaluate possible sources of sediment-derived micronutrients and estimate sediment-ocean mixing rates. We present the first coupled, short-lived radium isotope $\left({ }^{223} \mathrm{Ra}\right.$ and $\left.{ }^{224} \mathrm{Ra}\right)$ measurements from Antarctic waters, both present at very low activities (mean 0.155 and $3.21 \mathrm{dpm} \mathrm{m}^{-3}$, respectively), indicating much lower radium inputs than in other coastal environments. Longer-lived ${ }^{228} \mathrm{Ra}$ activity was also lower than existing nearshore values, but higher than open ocean waters, indicating some degree of coastal radium input on timescales exceeding the week-to-month range reflected by ${ }^{223} \mathrm{Ra}$ and ${ }^{224} \mathrm{Ra}$. Using a simple diffusion model along a shore to mid-bay transect, effective horizontal eddy diffusivity estimates ranged from $0.22-0.83 \mathrm{~m}^{2} \mathrm{~s}^{-1}$ from ${ }^{223} \mathrm{Ra}$ and ${ }^{224} \mathrm{Ra}$, respectively, much lower than already-low mixing estimates for the Southern Ocean. Significant radium enrichment and much faster mixing $\left(18 \mathrm{~m}^{2} \mathrm{~s}^{-1}\right)$ was found near a marine-terminating glacier and consequently any sediment-derived micronutrient inputs in this location are more probably dominated by glacial processes than groundwater, land runoff, or marine sediment sources.
\end{abstract}

Received 28 April 2012, accepted 13 August 2012, first published online 29 October 2012

Key words: actinium-227, glacial inputs, horizontal eddy diffusivity, land-ocean interface, Radium Delayed Coincidence Counter (RaDeCC), Ryder Bay

\section{Introduction}

The western Antarctic Peninsula (WAP), a region of high phytoplankton production supporting a large and productive food web, is currently undergoing the most pronounced recent rapid regional warming in the southern hemisphere (Vaughan et al. 2003). Average air temperature on the WAP has increased at a rate of $3.6 \pm 1.4^{\circ} \mathrm{C}$ per century, several times the global average (Vaughan et al. 2003). The majority of glaciers in the region are retreating, and the rate of this retreat is accelerating (Cook et al. 2005). At sea, an increase of $>1{ }^{\circ} \mathrm{C}$ has been recorded in the surface waters in summer, decreasing to near zero at $100 \mathrm{~m}$ depth (Meredith \& King 2005). There has also been a significant reduction in sea ice duration, with trends of later advance and earlier retreat in the Marguerite Bay area (Stammerjohn et al. 2008).

Unique in its proximity to the Antarctic Circumpolar Current (ACC), the WAP is subject to frequent incursions of Circumpolar Deep Water (CDW), which transports heat, salt and nutrients (Klinck 1998) onto the shelf, thereby influencing water mass properties and productivity along the WAP. Martinson et al. (2008) showed increasing trends in ocean heat content over the shelf, consistent with an increase in frequency of CDW incursions, believed to be at least partially driven by changes in atmospheric circulation (Martinson et al. 2008, Meredith et al. 2010). The observed changes in glacial retreat are also consistent with warmer waters, as it has been shown that the temperature of marine waters can significantly impact the melt rates of marineterminating glaciers (Pritchard et al. 2012).

From a biological perspective, a key influence on primary productivity along the WAP is stratification, as a more stable water column provides higher average light levels to cells in near-surface waters, thus encouraging phytoplankton growth (Venables et al. in press). Changes in freshwater inputs, heat content, and the associated changes in sea ice cover can affect stratification, and 
therefore productivity in this region. Indeed, phytoplankton dynamics already show changes linked to sea ice cover and stratification in both the northern and southern regions of the WAP (Montes-Hugo et al. 2009). In addition to light, growth of phytoplankton in Southern Ocean waters can be further limited by availability of micronutrients, primarily iron (Hoffmann et al. 2008). Freshwater inputs (surface runoff, glacial meltwater and groundwater) are clearly important to biological production due to their role in stratification, but are also a potential source of micronutrients such as iron (Raiswell 2011), an element known to limit phytoplankton productivity in large regions of the Southern Ocean.

To address these topics, radium ( $\mathrm{Ra}$ ) in seawater was measured at a coastal Antarctic site at the WAP. Radium is produced continuously in both continental and deep sea sediments by the decay of the particle reactive element thorium (Th). Radium occurs naturally in seawater as four radioisotopes: the short-lived isotopes ${ }^{223} \mathrm{Ra}$ and ${ }^{224} \mathrm{Ra}$ (halflife $\left(t_{1 / 2}\right)=11.435$ days and $t_{1 / 2}=3.66$ days, respectively), and the long-lived ${ }^{226} \mathrm{Ra}$ and ${ }^{228} \mathrm{Ra}\left(\mathrm{t}_{1 / 2}=1600\right.$ years and $t_{1 / 2}=5.75$ years, respectively). Radium Delayed Coincidence Counting (RaDeCC), a radon (Rn) detection system proposed for use with $\mathrm{Ra}$ isotopes by Moore \& Arnold (1996), allows measurement of ${ }^{223} \mathrm{Ra}$ and ${ }^{224} \mathrm{Ra}$ in the field, as well as activity of progenitor radionuclides (actinium $\left({ }^{227} \mathrm{Ac}\right)$ and ${ }^{224} \mathrm{Ra}_{\text {supported }}\left(={ }^{228} \mathrm{Th}\right)$, respectively) following the decay of the short-lived isotopes.

The information obtained by $\mathrm{RaDeCC}$ analysis covers isotopes of different half-lives, as well as of different sources. The concentration of $\mathrm{Ra}$ isotopes is highest at sediment margins due to the Th source, and decreases away from these margins due to dilution and radioactive decay. In the case of ${ }^{227} \mathrm{Ac}$, the dominant source is deep water, open ocean sediments, where low sediment accumulation rates and deep overlying water columns lead to higher accumulation of the parent isotope than in shallow shelf settings (Geibert et al. 2002). The different sources and decay rates can be exploited to detect and differentiate multiple inputs (e.g. for different groundwater reservoirs) as well as to estimate rates of the processes affecting these inputs on different timescales. In the last two decades, the short-lived isotopes of $\mathrm{Ra}$ have been used in the Southern Ocean to investigate coastal mixing rates and eddy diffusivity coefficients (Charette et al. 2007), water mass pathways (van Beek et al. 2008), iron inputs (Dulaiova et al. 2009) and terrigenous material from icebergs (Shaw et al. 2011).

The aim of this study was to use Ra isotopes to further constrain the sources of surface water in Ryder Bay and the extent to which they interact with sediments, while establishing a baseline against which any future change in $\mathrm{Ra}$ distributions may be interpreted. These Ra radioisotopic data are the most southerly $\left(67^{\circ} 34.02^{\prime} \mathrm{S}\right)$ reported to date. The relative importance of surface water sources, marine

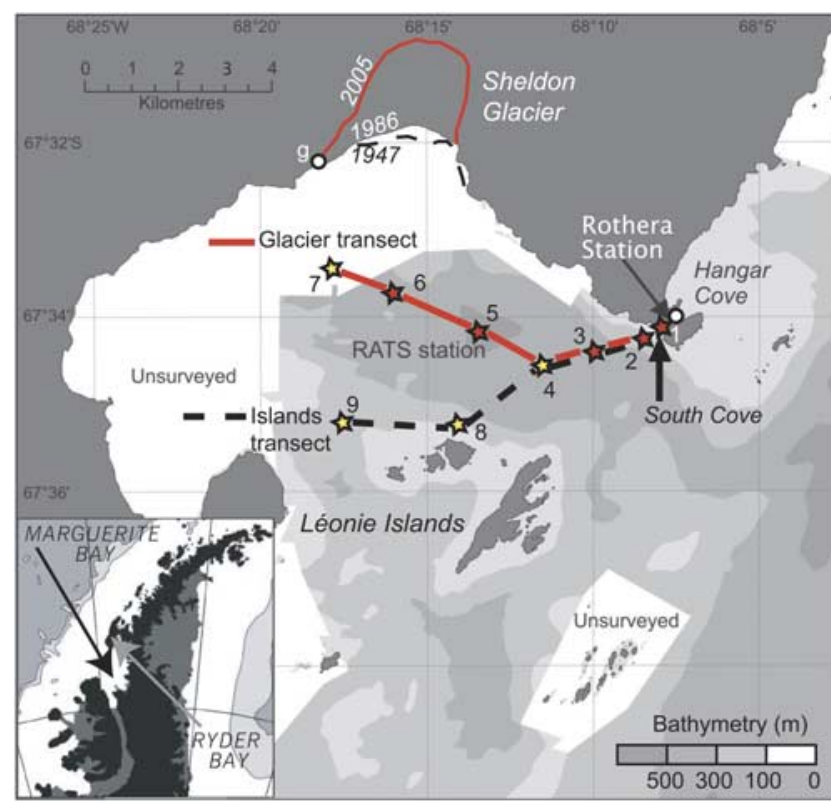

Fig. 1. Station numbers and locations in Ryder Bay. Red stations sampled 13-14 February, yellow stations sampled 25 February. Maximum depth is $520 \mathrm{~m}$ (at station 5, which is also the Rothera Oceanographic and Biological Time Series monitoring site). Station 1 is within South Cove, and is adjacent to the British Antarctic Survey's Rothera Research Station. Also shown is the edge of Sheldon Glacier, and the point used for glacially-derived mixing rates (denoted by "g").

and glacial sediment interaction, and the timescales on which mixing processes occur will aid in understanding not only oceanographic processes and local circulation patterns, but also trace metal availability in a region of very rapid change (Wallace et al. 2008, Meredith et al. 2010).

\section{Background}

\section{Study site and oceanographic context}

Ryder Bay is a shallow (maximum c. $500 \mathrm{~m}$ ) coastal embayment at the northern end of Marguerite Bay (Adelaide Island; Fig. 1), and is subject to processes that influence physical and biogeochemical conditions along the coastal WAP region (e.g. seasonal ice cover, glacial inputs). Largely representative of Marguerite Bay (Clarke et al. 2008), it is the site of the Rothera Oceanographic and Biological Time Series (RaTS) programme conducted by the British Antarctic Survey at nearby Rothera Research Station. This programme has monitored water column conditions and biological activity year-round in Ryder Bay since 1997 (Clarke et al. 2008). The accessibility of the RaTS site and long-term environmental dataset make this an ideal location for investigating mixing rates and sediment interaction in coastal WAP waters, in the context of understanding cycling of glacial- and marine sedimentderived micronutrients. 
The oceanography of the Marguerite Bay region, and the WAP more broadly, differs from other Antarctic shelf regions in its large fluxes of glacial meltwater from land and proximity to the ACC (Clarke et al. 2008). In Ryder Bay, use of oxygen isotopes has identified meteoric (glacial and snow) water as the dominant source of the freshwater inputs to Antarctic Surface Water (AASW) during summer, as opposed to melting sea ice (Meredith et al. 2010). The contribution of this meteoric water to the surface mixed layer varies annually, but is typically $2-6 \%$, compared with maximum $2 \%$ sea ice meltwater (Meredith et al. 2010). As such, the glacial influence in Ryder Bay surface waters is likely to be near the upper limit of the range relevant to the WAP (Clarke et al. 2008, and references therein).

Water masses along the WAP, as well as in Marguerite Bay and Ryder Bay, are well described (e.g. Clarke et al. 2008, Meredith et al. 2010). Briefly, the dominant water mass at depth derives from warm $\left(>1.0^{\circ} \mathrm{C}\right)$, high-nutrient CDW, which intrudes onto the continental shelf in relatively unmodified form (Martinson et al. 2008) due to the local absence of an Antarctic Slope Front (Klinck 1998). While CDW can be divided into upper (UCDW) and lower (LCDW) water masses, LCDW is present only in deep troughs (Moffat et al. 2008) and it is UCDW that dominates above the continental shelf. Upward mixing of UCDW provides heat and macronutrients to the nearsurface layers, and studies indicate that this mixing occurs primarily in coastal and shallow regions (Howard et al. 2004, Wallace et al. 2008). Above the UCDW, surface waters cool and gain salt during sea ice formation in autumn and winter, resulting in a seasonally deep mixed layer. The remnant of this persists into summer as a temperature minimum layer at depths around $100 \mathrm{~m}$, termed winter water (WW). During summer, this WW layer is capped at the surface by lighter waters that have been warmed by insolation and freshened by meltwater, producing AASW.

\section{Methods}

\section{Sample collection and processing}

Samples for $\mathrm{RaDeCC}$ analysis were collected from a small boat using a $12 \mathrm{~V}$ impeller pump attached to acid-cleaned $(10 \% \mathrm{HCl})$ silicon tubing. The tubing was rinsed with at least 251 of seawater before collecting an appropriate volume (110-1801) of seawater from $10 \mathrm{~m}$ depth into clean 201 containers. Five samples were collected on 13 and 14 February 2010, along a transect from shore to the RaTS site, which is located c. $2 \mathrm{~km}$ from shore in Ryder Bay (station 5; Fig. 1). Mixing rates derived from RaDeCC measurements along this line were used to assess the potential of sediment-derived nutrient sources for nearsurface productivity at this site. Following this transect, four additional samples were collected on 25 February 2010 , in order to investigate potential input signals from nearby islands and Sheldon Glacier. Sampling transects are shown in Fig. 1.

Samples were slowly (c. $200 \mathrm{ml} \mathrm{min}^{-1}$; van Beek et al. 2008) passed through a column filled with $c$. $20 \mathrm{~g}$ looselypacked $\mathrm{MnO}_{2}$-impregnated acrylic fibre, which quantitatively adsorbs $\mathrm{Ra}$ from seawater ( $97 \%$ extraction for samples up to $400 \mathrm{1}$; Moore 2008). The Mn-fibre was then rinsed with Milli-Q water (Millipore systems) to remove salts and particles. Excess water was removed by squeezing, and a moisture to fibre ratio of $0.3-1 \mathrm{~g}_{\mathrm{H} 2 \mathrm{O}}$ : $\mathrm{g}_{\text {fibre }}$ was maintained in order to maximize movement of $\mathrm{Rn}$ from the columns to the counting chambers.

Columns were then introduced into the RaDeCC system, following full sample preparation and processing procedures as described by Moore (2008). Counting was performed for as long as possible whilst still allowing all samples from a single sampling event to be analysed within a two day period. Counting time averaged $1000 \mathrm{~min}$ per sample, and in all cases exceeded 400 min.

Raw counts were corrected as described by GarciaSolsona et al. (2008) and Moore (2008), and converted to ${ }^{223} \mathrm{Ra}$ and ${ }^{224} \mathrm{Ra}$ activities in decays per minute (dpm) using the efficiencies measured for each scintillation chamber (c. 0.35 and 0.60 , respectively). Detector efficiency was monitored using standards obtained from the International Atomic Energy Agency (Monte Carlo, Monaco) and prepared at LEGOS, OMP (Toulouse, France), according to published methods (Dimova et al. 2008, Moore 2008, Scholten et al. 2010). Standards were measured several times throughout the duration of the study to monitor detector efficiency. Problems have been reported with decay of ${ }^{227} \mathrm{Ac}$ standards $(\leq 12 \%$; Scholten et al. 2010 ) in the first c. 50 days after preparation, although we were unable to assess this for our standards due to the timing of preparation and measurement. As this would affect only absolute (not relative) activities and are within the error reported here, this effect is not considered further.

All samples were measured at least four times in order to correct for interference from longer-lived $\mathrm{Ra}$ isotopes. Initial counting was done as soon after collection as possible, and samples were re-counted after 8,21 , and $>90$ days to correct for interference from ${ }^{224} \mathrm{Ra},{ }^{224} \mathrm{Ra}$ supported by ${ }^{228} \mathrm{Th}$, and ${ }^{227} \mathrm{Ac}$, respectively.

Estimation of error followed the equations of GarciaSolsona et al. (2008), with minor changes to the error propagation in correcting for long-lived isotopes. In our case, the third and fourth counts were used to estimate ${ }^{228} \mathrm{Th}$ and ${ }^{277} \mathrm{Ac}$, respectively. Interference from these sources was assumed to be constant and therefore not corrected for time since sample collection. Ingrowth of ${ }^{228} \mathrm{Th}$ from ${ }^{228} \mathrm{Ra}$ was not accounted for, as this contributed $<1 \%$ of ${ }^{228} \mathrm{Th}$ in all cases. These long-lived interferences 


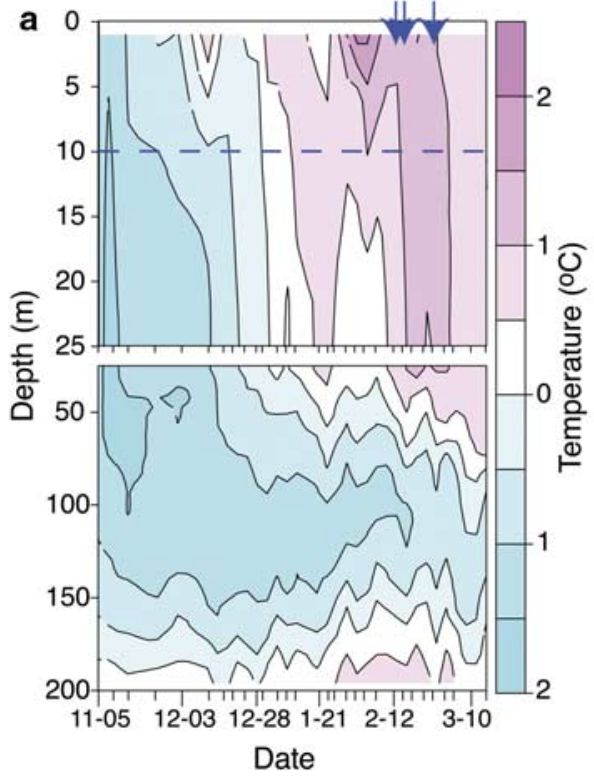

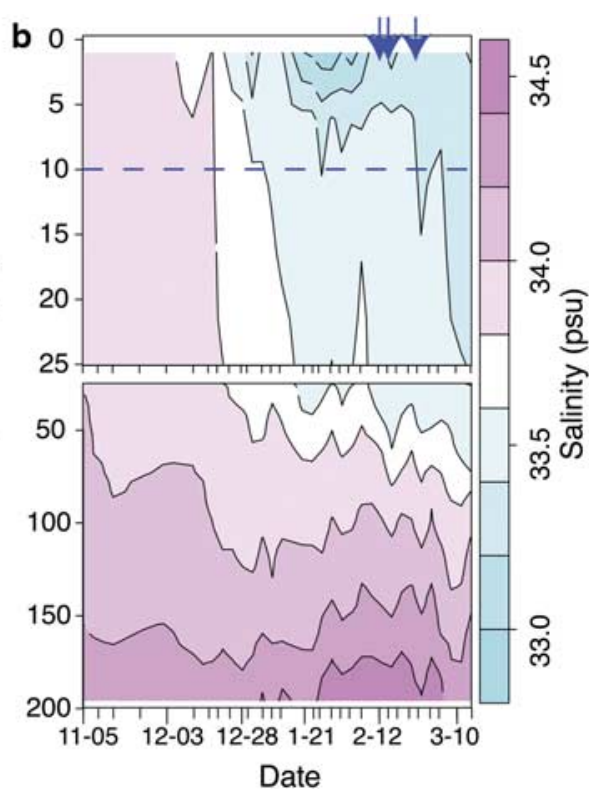

Fig. 2. a. Temperature, and b. salinity at station 5 (Rothera Oceanographic and Biological Time Series monitoring site). The top $25 \mathrm{~m}$ is expanded in the top plots. Arrows show dates of sampling, and dashed line marks sampling depth $(10 \mathrm{~m})$. Data courtesy of BAS. were subtracted from the time-corrected first counts according to the formula:

$$
A_{e x}=A_{1} \cdot e^{-\lambda \mathrm{t}}-A_{3 / 4},
$$

where $A_{e x}$ is the excess activity (at the time of collection), $A_{1}$ is the activity measured in the first count, $A_{3 / 4}$ is the activity measured during the third or fourth count, $\lambda$ is the decay constant of ${ }^{223} \mathrm{Ra}$ or ${ }^{224} \mathrm{Ra}$, and $t$ is the time between collection and the first count. Error combination followed the standard formula:

$$
\Delta A_{e x}^{2}=\left(\Delta A_{1} \cdot e^{-\lambda t}\right)^{2}+\Delta A_{3 / 4}^{2},
$$

where $\Delta$ denotes the absolute error of each term. Note that reported ${ }^{227} \mathrm{Ac}$ has not been corrected for activity supported by ${ }^{231} \mathrm{~Pa}$. Assuming ${ }^{231} \mathrm{~Pa}$ to be $c .0 .1 \mathrm{dpm} \mathrm{m}^{-3}$ (determined by Geibert et al. (2002) for surface waters south of the Antarctic Polar Front), the corrected ${ }^{227} \mathrm{Ac}_{\mathrm{ex}}$ would be $0.1 \mathrm{dpm} \mathrm{m}^{-3}$ less than the numbers shown here.

\section{Gamma counting}

Once the analyses using RaDeCC were performed, the Mnfibres were ashed $\left(16 \mathrm{~h}\right.$ at $\left.820^{\circ} \mathrm{C}\right)$ and transferred into sealed vials for gamma counting, following Charette et al. (2001). Radium isotopes adsorbed on $\mathrm{MnO}_{2}$ ash were analysed using low-background gamma-ray spectrometry at the underground laboratory of Ferrières (LAFARA, LAboratoire de mesure des FAibles RAdioactivités) located in the French Pyrénées, $100 \mathrm{~km}$ from Toulouse (van Beek et al. 2010, van Beek et al. in press). Radium-228 activities were determined using the 338,911 and $969 \mathrm{keV}$ peaks of ${ }^{228} \mathrm{Ac}$. Uncertainties reported for ${ }^{228} \mathrm{Ra}$ activities are errors due to counting statistics (one standard deviation).

\section{Results}

\section{Oceanographic context}

Seasonal records of water column conditions are available for station 5 (the RaTS Site) as part of the

Table I. Station details and short-lived radium activities from Radium Delayed Coincidence Counter (RaDeCC) analysis. As sample collection occurred on two occasions, station superscript " $b$ " denotes samples from the second sampling event. Distances given are to the nearest shoreline for each individual station. For glacial stations, distances are given to a point on the edge of Sheldon Glacier (denoted in the table by *, location shown on Fig. 1).

\begin{tabular}{lccccrr}
\hline Station & Latitude & Longitude & $\begin{array}{c}\text { Water column depth } \\
(\mathrm{m})\end{array}$ & $\begin{array}{c}\text { Distance } \\
(\mathrm{km})\end{array}$ & $\begin{array}{c}\text { Sample volume } \\
(\mathrm{l})\end{array}$ & $\begin{array}{c}{ }^{223} \mathrm{Ra}_{\mathrm{ex}} \\
\left(\mathrm{dpm} \mathrm{m} \mathrm{m}^{-3}\right)\end{array}$ \\
\hline 1 & -67.569 & -68.133 & 15 & 0.01 & 163.7 & $0.643 \pm 0.35$ \\
2 & -67.570 & -68.137 & 100 & 0.28 & 153.7 & $0.248 \pm 0.23$ \\
$\left(\mathrm{dpm} \mathrm{m}{ }^{-3}\right)$
\end{tabular}

bdl = below detection limit. 
Table II. Progenitor isotope activities from Radium Delayed Coincidence Counter (RaDeCC) analysis $\left({ }^{228} \mathrm{Th}\right.$ and $\left.{ }^{227} \mathrm{Ac}\right)$ and gamma spectroscopy $\left({ }^{228} \mathrm{Ra}\right)$. Also shown are ratios of ${ }^{228} \mathrm{Ra}:{ }^{227} \mathrm{Ac}$. As in Table I, station superscript " $b$ " denotes samples from the second sampling event. All activities are given in $\mathrm{dpm} \mathrm{m}^{-3}$.

\begin{tabular}{lcllc}
\hline Station & ${ }^{228} \mathrm{Th}$ & \multicolumn{1}{c}{${ }^{227} \mathrm{Ac}$} & \multicolumn{1}{c}{${ }^{228} \mathrm{Ra}$} & ${ }^{228} \mathrm{Ra}:{ }^{227} \mathrm{Ac}$ \\
\hline 1 & $3.40 \pm 0.26$ & $0.271 \pm 0.14$ & $22.4 \pm 1.4$ & $82 \pm 47$ \\
2 & $2.69 \pm 0.25$ & $0.400 \pm 0.14$ & $13.0 \pm 0.95$ & $33 \pm 14$ \\
3 & $\mathrm{bdl}$ & $0.338 \pm 0.12$ & $19.2 \pm 1.3$ & $57 \pm 24$ \\
$4^{\mathrm{b}}$ & $0.430 \pm 0.12$ & $0.378 \pm 0.19$ & $17.5 \pm 1.3$ & $46 \pm 27$ \\
5 & $0.776 \pm 0.14$ & $0.383 \pm 0.15$ & $19.8 \pm 1.5$ & $52 \pm 24$ \\
6 & $3.02 \pm 0.28$ & $0.052 \pm 0.072$ & $39.5 \pm 2.1$ & $760 \pm 1090$ \\
$7^{\mathrm{b}}$ & $1.83 \pm 0.26$ & $0.897 \pm 0.22$ & $17.1 \pm 1.3$ & $19 \pm 6$ \\
$8^{\mathrm{b}}$ & $2.59 \pm 0.28$ & $0.437 \pm 0.20$ & $16.8 \pm 1.6$ & $38 \pm 21$ \\
$9^{\mathrm{b}}$ & $0.764 \pm 0.14$ & $0.059 \pm 0.10$ & $13.0 \pm 1.2$ & $220 \pm 400$ \\
\hline
\end{tabular}

bdl = below detection limit.

RaTS monitoring programme (British Antarctic Survey, Cambridge, UK). Upper layer temperature and salinity data indicate a typical seasonal progression from well-mixed wintertime waters in November (with temperatures $<0^{\circ} \mathrm{C}$ and comparatively high salinity) to more stratified summer conditions characterized by warmer surface waters $\left(>1^{\circ} \mathrm{C}\right)$ and significant freshening due to meltwater input (salinity as low as $c$. 33.1; Fig. 2). Beneath the summertime surface layer, the WW layer is apparent as a temperature minimum at c. $100 \mathrm{~m}$ depth, with properties largely dictated by those of the previous winter mixed layer.

From these temperature and salinity records, it can be seen that physical conditions between the two sampling events were very similar, implying that no significant upwelling or mixing events occurred (such as might be expected during, for example, strong weather events), and that any lateral advection occurred within a relatively uniform water mass. We therefore interpret stations from both transects on the assumption that differences chiefly reflect steady-state diffusive and advective processes.

\section{Short-lived isotopes}

Activity of ${ }^{223} \mathrm{Ra}_{\mathrm{ex}}$ (below detection limit (bdl) $-0.649 \mathrm{dpm} \mathrm{m}^{-3}$ ) is considerably lower than that of ${ }^{224} \mathrm{Ra}_{\mathrm{ex}}\left(0.066-14.6 \mathrm{dpm} \mathrm{m}^{-3}\right)$, although both isotopes show very similar trends (Table I). Very low activities were found in the central, deep area of Ryder Bay (stations 3, 4 and 5; depth $>300 \mathrm{~m}$; hereafter "mid-bay"), on average 0.023 and $0.076 \mathrm{dpm} \mathrm{m}^{-3}$ for ${ }^{223} \mathrm{Ra}_{\mathrm{ex}}$ and ${ }^{224} \mathrm{Ra}_{\mathrm{ex}}$, respectively. The most pronounced enrichment is seen at station 1, nearest the shore (in South Cove, alongside Rothera Station) and in shallowest water depth $(<30 \mathrm{~m})$. This high activity decreases with distance from the shore, through stations $1-5$. An enrichment is also seen in the sample nearest the Léonie Islands group (station 8), which is sustained in ${ }^{223} \mathrm{Ra}_{\mathrm{ex}}$ at station 9, but not in ${ }^{224} \mathrm{Ra}_{\text {ex }}$. The two samples taken from nearer to Sheldon Glacier (stations 6 and 7) exhibit higher activities of
${ }^{224} \mathrm{Ra}_{\mathrm{ex}}$ relative to mid-bay samples. This enrichment is also seen in ${ }^{223} \mathrm{Ra}_{\mathrm{ex}}$ at station 7 , although station $6{ }^{223} \mathrm{Ra}_{\mathrm{ex}}$ was below detection limits.

Many of the values reported here, especially those from central Ryder Bay, are below the detection limits estimated by Moore (2008) for $\mathrm{RaDeCC}$ analysis $(0.2$ and 0.5 total collected dpm for ${ }^{223} \mathrm{Ra}$ and ${ }^{224} \mathrm{Ra}$, respectively). However, the background activity measured with our RaDeCC system was much lower than all samples analysed (mean 3\% and 9\% of raw counts for 219 and 220 channels, respectively) and reproducibility was good (c. $20 \%$ standard deviation for three consecutive readings). Furthermore, samples from similar areas display much less variation than the error of individual samples (see Discussion). Therefore we consider our results above the detection limit of $\mathrm{RaDeCC}$ analysis, except in the three cases noted in Table I.

\section{Parent isotopes}

The average activity of ${ }^{227} \mathrm{Ac}$ is lower than that of ${ }^{228} \mathrm{Th}$ $\left({ }^{227} \mathrm{Ac}: \quad 0.052-0.897 \mathrm{dpm} \mathrm{m}^{-3}\right.$; ${ }^{228} \mathrm{Th}: \quad$ bdl- $3.40 \mathrm{dpm} \mathrm{m}^{-3}$; Table II), in keeping with the relationship between the daughter nuclides $\left({ }^{223} \mathrm{Ra}_{\mathrm{ex}}<{ }^{224} \mathrm{Ra}_{\mathrm{ex}}\right)$. The spatial distribution of ${ }^{228} \mathrm{Th}$ is similar to that of ${ }^{223} \mathrm{Ra}_{\mathrm{ex}}$ and ${ }^{224} \mathrm{Ra}_{\mathrm{ex}}$, with marked enrichment near Rothera station (South Cove, stations 1 and 2) and nearest the islands (station 8). As with ${ }^{224} \mathrm{Ra}_{\mathrm{ex}}$, the increase in ${ }^{228} \mathrm{Th}$ near station 8 is not seen at station 9 , slightly further from land and in deeper water.

The distribution of ${ }^{227} \mathrm{Ac}$ shows very different trends from the short-lived $\mathrm{Ra}$ isotopes. The highest activity reported $\left(0.897 \pm 0.217 \mathrm{dpm} \mathrm{m}^{-3}\right)$ is at station 7 , nearest Sheldon Glacier, with all other stations displaying less than half of this value. Excluding station 7, the trends of ${ }^{227} \mathrm{Ac}$ are roughly opposite to those of the Ra suite, with mid-bay stations displaying high values $\left(0.37 \pm 0.02 \mathrm{dpm} \mathrm{m}^{-3}\right)$, and nearshore stations $(1,2,8,9)$ having slightly lower activities of $0.29 \pm 0.17 \mathrm{dpm} \mathrm{m}^{-3}$, although these are not statistically different to mid-bay waters.

\section{Long-lived Ra isotopes}

The long-lived $\mathrm{Ra}$ isotope ${ }^{228} \mathrm{Ra}$ shows slightly different trends from the short-lived isotopes (Table II). Station 1 again shows enrichment, although this is minor compared with the enrichment seen in ${ }^{223} \mathrm{Ra}_{\mathrm{ex}},{ }^{224} \mathrm{Ra}_{\mathrm{ex}}$ and ${ }^{228} \mathrm{Th}$. Stations $3-5$ show relatively consistent values $\left(c .17 .5 \mathrm{dpm} \mathrm{m}^{-3}\right)$ but, in contrast to other Ra isotopes, station 2 displays lower activity than the mid-bay stations. The highest ${ }^{228} \mathrm{Ra}$ activity was measured at station 6 , coincident with a peak (although not to maximum activity) of ${ }^{228} \mathrm{Th}$.

Due to the different sources of each radioisotope, ratios such as ${ }^{228} \mathrm{Ra}^{227} \mathrm{Ac}$ can be helpful in distinguishing between different source waters. Station 6 shows a peak 
in the ratio of ${ }^{228} \mathrm{Ra}:{ }^{227} \mathrm{Ac}$ (Table II). A second peak is seen at station 9, and a minimum at station 7 , although these latter variations are driven by the activity of ${ }^{227} \mathrm{Ac}$, and within error these ratios are not significantly different from the average for other stations.

\section{Discussion}

\section{Radium sources to Ryder Bay}

From the activities of ${ }^{223} \mathrm{Ra}_{\mathrm{ex}}$ and ${ }^{224} \mathrm{Ra}_{\mathrm{ex}}$ along both transects, we identify sources near South Cove, the Léonie Islands, and Sheldon Glacier. Station 1, with the shallowest water depth and short distance from shore, would be expected to exhibit the greatest activity, and indeed shows strong enrichment in ${ }^{223} \mathrm{Ra}_{\mathrm{ex}},{ }^{224} \mathrm{Ra}_{\mathrm{ex}}$ and ${ }^{228} \mathrm{Th}$.

Radium-223, in excess of that supported by decay of dissolved ${ }^{227} \mathrm{Ac}$, is produced from the decay of ${ }^{227} \mathrm{Th}$, which is strongly bound to sediments. Thus ${ }^{223} \mathrm{Ra}_{\mathrm{ex}}$ displays a strong source along any interface (land-water or sediment-water). A clear enrichment in ${ }^{223} \mathrm{Ra}_{\mathrm{ex}}$ is evident at station 1 (Table I), to values of $0.65 \mathrm{dpm} \mathrm{m}^{-3}$. To our knowledge, these are the first coupled short-lived Ra isotope activities reported for Antarctic waters. The only published ${ }^{223} \mathrm{Ra}_{\mathrm{ex}}$ activities from coastal Southern Ocean waters are $0.42-5.2 \mathrm{dpm} \mathrm{m}^{-3}$, from waters within $2.6 \mathrm{~km}$ of the sub-Antarctic Iles Crozet (Charette et al. 2007), generally higher than the range for this study (bdl-0.65 $\mathrm{dpm} \mathrm{m}^{-3}$ ) but in keeping with activity in our South Cove sample. Further offshore from Iles Crozet, however, ${ }^{223} \mathrm{Ra}_{\mathrm{ex}}$ dropped to $0.02-0.19 \mathrm{dpm} \mathrm{m}^{-3}$ (c. $12 \mathrm{~km}$ from shore; Charette et al. 2007), in close agreement with the values reported here for distances of $0.5-2 \mathrm{~km}$.

As with ${ }^{223} \mathrm{Ra}_{\mathrm{ex}},{ }^{224} \mathrm{Ra}_{\mathrm{ex}}$ shows a strong signal of enrichment from sediments due to its Th progenitor. The decay of ${ }^{228} \mathrm{Ra}$, present mainly in the dissolved phase, produces ${ }^{228} \mathrm{Ac}$, which quickly decays $\left(\mathrm{t}_{1 / 2}=6.15 \mathrm{~h}\right)$ to ${ }^{228} \mathrm{Th}$. This ${ }^{228} \mathrm{Th}$ is rapidly scavenged and slowly releases ${ }^{224} \mathrm{Ra}$ from sediments. In coastal areas, ${ }^{228} \mathrm{Th}$ may also be sourced from the surrounding rock in addition to its production within the water column, and indeed this terrigenous source is much greater than the marine source. Published values for ${ }^{224} \mathrm{Ra}_{\mathrm{ex}}$ range from $3.1-47 \mathrm{dpm} \mathrm{m}^{-3}$ (Iles Crozet; Charette et al. 2007) and $8-17 \mathrm{dpm} \mathrm{m}^{-3}$ (coastal Antarctic Peninsula surface waters; Dulaiova et al. 2009). Only station 1 of the Ryder Bay samples falls within this range $\left(14.6 \mathrm{dpm} \mathrm{m}^{-3}\right)$, although other nearshore samples clearly show this land-interface signal.

This shore-derived signal is transported offshore, and stations 2 and 8 , both at similar distances from the shoreline (South Cove and Leonie Islands, respectively) and at similar depths, display very similar activities of all nuclides measured here (Tables I \& II). Station 9 also shows some enrichment in ${ }^{223} \mathrm{Ra}_{\mathrm{ex}}$ relative to mid-bay samples, which does not appear in the other isotopes. This could be explained by slow mixing such that ${ }^{224} \mathrm{Ra}$, with its shorter half-life,

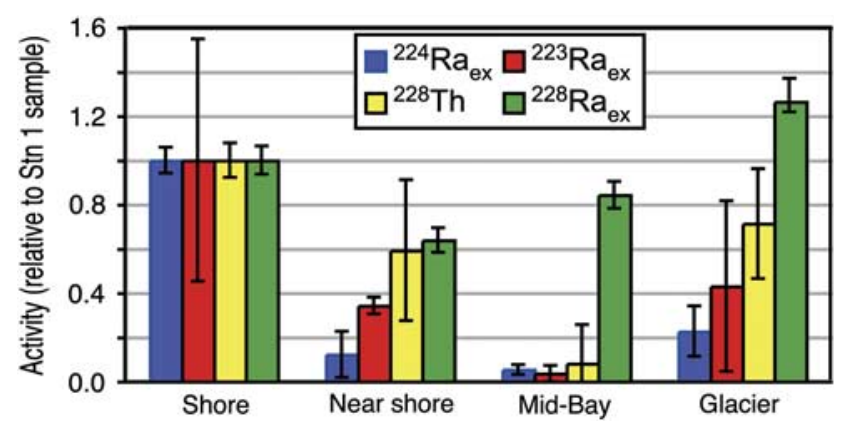

Fig. 3. Radium activities grouped by location type, and relative to the highest measured activity (in all cases at station 1 (shore), error bars show sample uncertainty). Nearshore stations: 2, 8 and 9. Mid-bay stations: 3, 4 and 5. Glacier stations: 6 and 7. Error bars on nearshore, mid-bay and glacier stations represent one standard deviation, except in the case of ${ }^{223} \mathrm{Ra}_{\mathrm{ex}}$ at the glacier station where sample error is shown because only one sample was above the detection limit.

would decay more quickly than ${ }^{223} \mathrm{Ra}$ during a given period of mixing. Additionally, the difference in signal between these two isotopes may be small, as the errors on ${ }^{223} \mathrm{Ra}_{\mathrm{ex}}$ are relatively large due to the much lower activity of this isotope and sampling constraints preventing the collection of larger volume samples. This signal of higher activities in the nearshore sampling locations is consistent with a $\mathrm{Ra}$ source from surrounding rocks, and/or production of $\mathrm{Ra}$ in shallow marine sediments.

Notably, there are also enrichment signals towards Sheldon Glacier which, in the case of ${ }^{224} \mathrm{Ra}_{\mathrm{ex}},{ }^{228} \mathrm{Th}$ and ${ }^{228} \mathrm{Ra}$, are very high given the distance from land at these stations. Glacial flour, subglacial and/or surface meltwater flows, or sediment/seawater interaction beneath the ice shelf could all potentially act as sources for Ra enrichment near Sheldon Glacier. While we are unable to discriminate here between these processes, it is probable that the signal is at least partly derived from the glacier (and entrained terrigenous material) itself. Shaw et al. (2011) reported ${ }^{224} \mathrm{Ra}_{\mathrm{ex}}$ activities of $c .1 .2-9.4 \mathrm{dpm} \mathrm{m}^{-3}$ in surface waters near free-drifting icebergs in the Weddell Gyre, showing that glacial material alone can account for a highly significant ${ }^{224} \mathrm{Ra}_{\mathrm{ex}}$ enrichment in the absence of any bottom sediments.

There is some variability between the activities at stations 6 and 7 , although records of $\delta^{18} \mathrm{O}$ (Meredith et al. in press) in water samples at the RaTS site indicate similar proportions of meteoric (glacial/snow) water in the water column on both sampling days. Thus we infer that glacial sources of Ra are highly variable, as might be expected given the potential for different processes (ice melt versus subglacial sediment-water mixing) to contribute terrigenous material, in addition to potential differences in the composition of that material. Additionally, small-scale flow filaments could contribute to different Ra activity being collected from these two stations, 
Table III. Mean (range) activities for short-lived Ra isotopes $\left({ }^{223} \mathrm{Ra}_{\mathrm{ex}}\right.$ and $\left.{ }^{224} \mathrm{Ra} \mathrm{a}_{\mathrm{x}}\right)$ and their parent isotopes $\left({ }^{227} \mathrm{Ac}\right.$ and $\left.{ }^{228} \mathrm{Th} /{ }^{228} \mathrm{Ra}\right)$. Ranges of activities reported from similar environments are also given for comparison. All activities are given in $\mathrm{dpm} \mathrm{m}^{-3}$.

\begin{tabular}{|c|c|c|c|c|c|c|}
\hline Source & Location & ${ }^{223} \mathrm{Ra}_{\mathrm{ex}}$ & ${ }^{224} \mathrm{Ra}_{\mathrm{ex}}$ & ${ }^{227} \mathrm{Ac}$ & ${ }^{228} \mathrm{Th}$ & ${ }^{228} \mathrm{Ra}$ \\
\hline Dulaiova et al. 2009 & $\begin{array}{l}\text { Surface, } \\
\text { coastal Antarctic Peninsula }\end{array}$ & & $(8-17)$ & & & $(10-20)$ \\
\hline Charette et al. 2007 & $\begin{array}{l}\text { Inshore (to } 12.5 \mathrm{~km} \text { ), } \\
\text { Iles Crozet }\end{array}$ & $(0.02-5.2)$ & $(1.4-47)$ & & & $(8.9-41)$ \\
\hline Van Beek et al. 2008 & $\begin{array}{l}\text { Surface, } \\
\text { offshore Iles Kerguelen }\end{array}$ & & & & & $(0.4-3.9)$ \\
\hline Shaw \& Moore 2002 & $\begin{array}{l}\text { Surface, } \\
\text { offshore South Shetland Islands }\end{array}$ & & & 0.20 & & \\
\hline Hanfland 2002 & $\begin{array}{l}\text { Surface, shelf waters } \\
\text { Antarctic Peninsula } \\
\text { and Weddell Sea }\end{array}$ & & & & & $(2-20)$ \\
\hline $\begin{array}{l}\text { Moore } 2000 \mathrm{a}^{\mathrm{a}} \text {, } \\
\text { Moore \& Arnold 1996b }\end{array}$ & Typical coastal values & $22.4^{\mathrm{a}}(4.6-300)^{\mathrm{b}}$ & $144^{\mathrm{a}}(4.9-660)^{\mathrm{b}}$ & & & \\
\hline
\end{tabular}

${ }^{\mathrm{a}}$ From the South Atlantic Bight.

${ }^{\mathrm{b}}$ From the Mississippi and Atchafalaya River mixing zones, and Tampa Bay, Florida (for samples with salinity $>27$ parts per thousand). $\mathrm{bdl}=$ below detection limit.

even if sediment composition were invariant. Despite this variability, the average activities at stations nearest Sheldon Glacier show a clear signal of all four Ra nuclides (Fig. 3). "Glacier" stations exhibit statistically higher ${ }^{224} \mathrm{Ra}_{\mathrm{ex}}$ and ${ }^{228} \mathrm{Th}$ than mid-bay samples $\left(3.30 \mathrm{dpm} \mathrm{m}^{-3}\right.$ vs $0.78 \mathrm{dpm} \mathrm{m}^{-3}, \quad P=0.0344 ; \quad 0.24$ vs $0.027, \quad P=0.050$; respectively, two-sample $t$-tests). The two glacier stations show very different ${ }^{223} \mathrm{Ra}_{\mathrm{ex}}$ activities, consistent with high variability of glacial sources. One sample is below the detection limit, but activity nearest the glacier $\left(0.277 \mathrm{dpm} \mathrm{m}^{-3}\right.$, station 7) is an order of magnitude higher than the mid-bay average of $0.023 \mathrm{dpm} \mathrm{m}^{-3}$, indicating an intermittent but significant glacial source of ${ }^{223} \mathrm{Ra}_{\mathrm{ex}}$, as with ${ }^{224} \mathrm{Ra}$.

Trends in ${ }^{228} \mathrm{Ra}$ are also consistent with a glacial source, as station 6 displays pronounced enrichment to an activity approximately twofold higher than at station 1 (Table II). While variable, average ${ }^{228} \mathrm{Ra}$ was $28.3 \mathrm{dpm} \mathrm{m}^{-3}$ near the glacier, compared to $18.9 \mathrm{dpm} \mathrm{m}^{-3}$ in mid-bay stations, although this difference was not statistically significant $(P=0.236)$. The highly significant enrichment at station 6 leads to elevated ${ }^{228} \mathrm{Ra}:{ }^{227}$ Ac ratios (Table II) compared to all other stations, suggestive of a distinct water source that is enriched in ${ }^{228} \mathrm{Ra}$. This enrichment, coupled with the very low ${ }^{227}$ Ac activity (produced in deep ocean sediments - see below) indicates a terrestrial source, consistent with glacial meltwater. In keeping with its much longer half-life $\left(t_{1 / 2}=5.75\right.$ years $)$, the distribution of ${ }^{228} \mathrm{Ra}$ shows less variability between the different location types than the shorter-lived isotopes. Due to its long half-life, variations in ${ }^{228} \mathrm{Ra}$ activity within Ryder Bay must reflect dilutive processes, rather than decay during advection which is seen in the shorter-lived isotopes. The increase in ${ }^{228} \mathrm{Ra}$ activity near the glacier is consistent with an input of enriched water to the surface, as by a thin lens of glacial meltwater. Even a modest extent of mixing with the underlying water column would then dilute this signal due to the very small relative volume of a thin meltwater lens, in accordance with the lower values of ${ }^{228} \mathrm{Ra}$ in mid-bay stations.

\section{Deep water renewal}

Activities of the short-lived isotopes of $\mathrm{Ra}$ and their progenitors are low compared to many coastal areas (Table III). Few studies have examined Ra isotopes in Southern Ocean locations, but the scarce data suggest that as a whole the Southern Ocean displays low Ra activity, except for ${ }^{226} \mathrm{Ra}$ (Hanfland 2002) which decays much more slowly $\left(t_{1 / 2}=1600\right.$ years $)$. Reported activities for ${ }^{223} \mathrm{Ra}$ and ${ }^{224} \mathrm{Ra}$ in coastal areas of the Antarctic Peninsula (Dulaiova et al. 2009) and Iles Crozet (Charette et al. 2007), as well as waters offshore of Iles Kerguelen (van Beek et al. 2008) are higher on average than those reported here, but the ranges overlap in all cases.

For coastal waters, the activities of short-lived $\mathrm{Ra}$ isotopes reported here are extremely low. Studies from the Iles Crozet and South Shetland Islands (Charette et al. 2007, Dulaiova et al. 2009) reported similar, very low ranges compared to locations outside the Southern Ocean. The South Atlantic Bight, for example, displays inshore Ra activities of 22.4 and $144 \mathrm{dpm} \mathrm{m}^{-3}\left({ }^{223} \mathrm{Ra}_{\mathrm{ex}}\right.$ and ${ }^{224} \mathrm{Ra}_{\mathrm{ex}}$, respectively; Moore 2000a) - up to four orders of magnitude higher than those in Ryder Bay. However, even other Southern Ocean samples, when compared by distance from shore, have high activity compared to Ryder Bay. As such, the ${ }^{223} \mathrm{Ra}_{\mathrm{ex}}$ and ${ }^{224} \mathrm{Ra}_{\mathrm{ex}}$ activities in Ryder Bay are among the lowest reported for an inshore $(<5 \mathrm{~km})$ setting. 
Activities are especially low in the case of mid-Ryder Bay samples, where mean ${ }^{223} \mathrm{Ra}_{\mathrm{ex}}$ was $0.023 \mathrm{dpm} \mathrm{m}^{-3}$, and that of ${ }^{224} \mathrm{Ra}_{\mathrm{ex}}$ was $0.76 \mathrm{dpm} \mathrm{m}^{-3}$. Activity of ${ }^{223} \mathrm{Ra}_{\mathrm{ex}}$ offshore from Iles Crozet is reported as $0.02-0.19 \mathrm{dpm} \mathrm{m}^{-3}$ (c. $12 \mathrm{~km}$ from shore; Charette et al. 2007), and the Ryder Bay values are in keeping with the lower limit of this range despite being significantly closer to shore. Low values of ${ }^{224} \mathrm{Ra}_{\mathrm{ex}}$ were also observed in Southern Ocean surface waters: Dulaiova et al. (2009) reported ${ }^{224} \mathrm{Ra}_{\mathrm{ex}}$ activities of 2-4 dpm m$~^{-3}$ above the continental shelf, while Drake Passage/ACC waters were found to contain no ${ }^{224} \mathrm{Ra}_{\mathrm{ex}}$. The activities measured here for mid-Ryder Bay samples are in keeping with offshore waters, suggesting limited input from sediment-water interaction, coastal runoff or submarine groundwater discharge. Taken together, the activities of both short-lived $\mathrm{Ra}$ isotopes in central Ryder Bay suggest an open ocean source for surface waters, with slow diffusion of $\mathrm{Ra}$ enrichment derived from interfaces (sediment-water and land-water).

The distribution of ${ }^{227} \mathrm{Ac}$ is very different from that of short-lived Ra species. Actinium-227 is produced from decay of ${ }^{231} \mathrm{~Pa}$, which itself is produced from ${ }^{235} \mathrm{U}$, an isotope with a near-uniform distribution throughout the global ocean. Upon production, ${ }^{231} \mathrm{~Pa}$ is rapidly scavenged, and builds up in slowly-accumulating deep sea sediments (Geibert et al. 2002). Thus the deep sea is a major source for the more soluble ${ }^{227} \mathrm{Ac}$ which diffuses out of the sediment into the overlying bottom water. Geibert et al. (2002) showed that UCDW and LCDW can be distinguished based on their ${ }^{227} \mathrm{Ac}$ activities, with the deeper LCDW having higher activity. However, Shaw \& Moore (2002) showed that in surface waters of the Southern Ocean, enrichment of ${ }^{227} \mathrm{Ac}$ can also be seen in continental shelf and coastal regions due to decay of terrigenous ${ }^{235} \mathrm{U}$ in shelf sediments: a global dataset of ${ }^{227} \mathrm{Ac}$ by delayed coincidence counting has demonstrated that ${ }^{227} \mathrm{Ac}$ is supplied to some extent by coastal environments (Geibert \& Vöge 2008).

The ${ }^{227} \mathrm{Ac}$ values reported here, with the exception of station 7, show highest activities in mid-bay samples $\left(0.37 \pm 0.02 \mathrm{dpm} \mathrm{m}^{-3}\right)$. The higher activity at station 7 may be due to a glacial source with extremely high spatial and temporal variability, as is indicated by the $\mathrm{Ra}$ isotopes. However, since there is no definitive single explanation for the higher values at station 7, we restrict discussion of ${ }^{227}$ Ac data to mid-bay stations. Most sites along the islands transect are within error of the mid-bay samples, and significant variations in ${ }^{227} \mathrm{Ac}$ activity would not be expected, as the very long half-life of ${ }^{227} \mathrm{Ac}$ (21.77 years) vastly exceeds the timescale relevant to circulation in Ryder Bay.

The mean mid-bay ${ }^{227}$ Ac activity of $0.37 \mathrm{dpm} \mathrm{m}^{-3}$ is somewhat higher than those reported by Shaw \& Moore (2002) for open Drake Passage surface waters (0.13$0.23 \mathrm{dpm} \mathrm{m}^{-3}$ ), and even for on-shelf sites around the South Shetland Islands and South America $\left(0.20-0.27 \mathrm{dpm} \mathrm{m}^{-3}\right)$.
The greater activity may either reflect interaction with the continental shelf or slope, or ${ }^{227}$ Ac-rich source waters. Geibert et al. (2002) studied ${ }^{227}$ Ac with depth in the Weddell Gyre and Drake Passage, finding that UCDW was characterized by ${ }^{227} \mathrm{Ac}_{\mathrm{ex}}$ activities of $0.2-0.4 \mathrm{dpm} \mathrm{m}^{-3}$ (equivalent to ${ }^{227} \mathrm{Ac}$ c. $0.43-0.75 \mathrm{dpm} \mathrm{m}^{-3}$ ). Waters in the Drake Passage were found to have slightly lower activities, with surface water reported at $0.10-0.27 \mathrm{dpm} \mathrm{m}^{-3}$ (Shaw \& Moore 2002) and $\mathrm{UCDW}(c .500 \mathrm{~m}){ }^{227}$ Ac activity measured as $0.37 \mathrm{dpm} \mathrm{m}^{-3}$ (supplemental data from Geibert et al. (2002); we compare ${ }^{227} \mathrm{Ac}$ activities rather than ${ }^{227} \mathrm{Ac}_{\mathrm{ex}}$ to avoid introducing any uncertainty arising from an estimation of the ${ }^{231} \mathrm{~Pa}$ correction for our data). The values measured in Ryder Bay, especially the mid-bay stations, are in better agreement with the ${ }^{227} \mathrm{Ac}$ of subsurface $(500 \mathrm{~m})$ Drake Passage waters than surface waters. Current understanding of regional circulation is that Marguerite Bay is subject to frequent but irregular incursions of UCDW at depth via Marguerite Trough (Martinson et al. 2008, Moffat et al. 2009), with CDW being the ultimate source of waters in Marguerite Bay and Ryder Bay. This water mixes up into the WW and AASW layers, with mixing expected to occur primarily in coastal and shallow regions (Wallace et al. 2008). Additionally, $\delta^{18} \mathrm{O}$ data at station 5 indicates that $>96 \%$ of the water at $15 \mathrm{~m}$ comes from CDW during the sampling period (Meredith et al. in press). The lack of enrichment in Ryder Bay ${ }^{227} \mathrm{Ac}$ relative to UCDW values indicates very little continental shelf input of ${ }^{227} \mathrm{Ac}$.

However, ${ }^{228} \mathrm{Ra}$ is higher than expected for open-ocean UCDW, indicating some recent interaction of the water mass with sediments, which also has the potential to contribute some ${ }^{227}$ Ac. Activity of ${ }^{228}$ Ra for Antarctic Polar Front and ACC waters has been reported as $0.25-2 \mathrm{dpm} \mathrm{m}^{-3}$ (see Charette et al. 2007). Our measurements are an order of magnitude higher than these open water values, but consistent with surface waters near Iles Crozet (8.9-41 $\mathrm{dpm} \mathrm{m}^{-3}$; Charette et al. 2007) and in the Weddell Gyre (21-32 $\mathrm{dpm} \mathrm{m}^{-3}$; Rutgers van der Loeff 1994). Despite being higher than more oceanic regions, the activities measured here are still much lower than temperate coastal areas (e.g. $75-246 \mathrm{dpm} \mathrm{m}^{-3}$ in the South Atlantic Bight; Moore 2000a), suggesting relatively minor ${ }^{228} \mathrm{Ra}$ inputs relative to river-influenced locations.

The elevated ${ }^{227} \mathrm{Ac}$ and ${ }^{228} \mathrm{Ra}$ activities in Ryder Bay can be explained by a combination of the UCDW source water and modest interaction with the continental shelf or shelfbreak. Indeed, the path of UCDW from the ACC onto the WAP shelf is consistent with a shelf-break or margin source, which has been proposed as a major contributor to oceanic micronutrient budgets (e.g. Jeandel et al. 2011). While ${ }^{228} \mathrm{Ra}$ indicates some continental shelf interaction, there is no observed enrichment in ${ }^{227} \mathrm{Ac}$ relative to offshore UCDW, which is as expected for a shelf setting. Relatively shallow depths $(c .500 \mathrm{~m})$ allow for limited ${ }^{231} \mathrm{~Pa}$ production, and a high rate of sediment accumulation on 

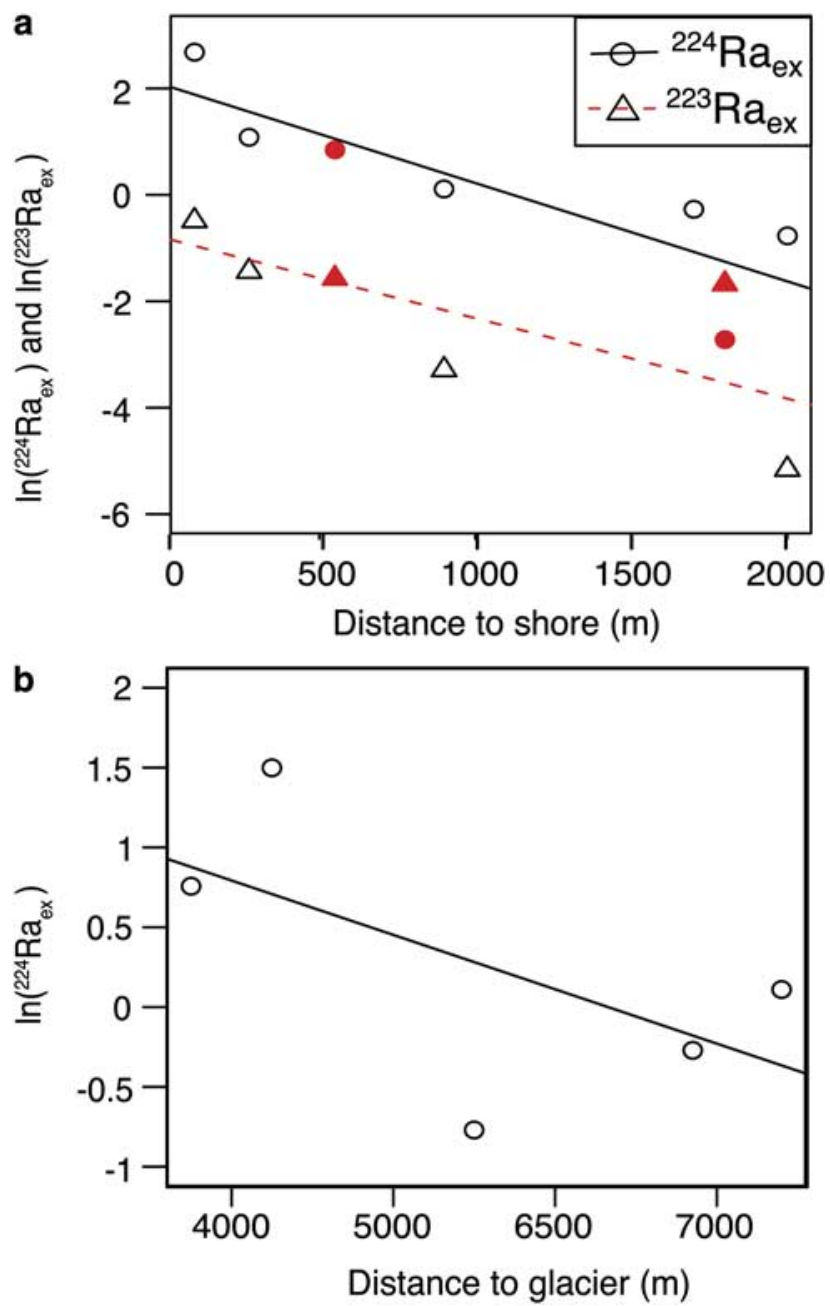

Fig. 4. a. Determination of effective eddy diffusivity coefficients $\left(k_{h}\right)$ based on activity of ${ }^{223} \mathrm{Ra}_{\mathrm{ex}}$ and ${ }^{224} \mathrm{Ra}_{\mathrm{ex}}$ versus distance for the islands transect. Due to the semienclosed nature of Ryder Bay, distance was measured to nearest land (including the islands), to better reflect a source of $\mathrm{Ra}$ in sediments which would be present along the entire shoreline, rather than solely at a fixed point such as South Cove. Shown are all stations along the islands transect as well as station 5 (the Rothera Oceanographic and Biological Time Series site). Filled symbols are those stations nearest the Léonie Islands group (stations 8 and 9); stations 1-5 are shown as open symbols. b. Effective eddy diffusivity coefficients $\left(k_{h}\right)$ from ${ }^{224} \mathrm{Ra}_{\mathrm{ex}}$ for the glacier transect. Glacier transect distances are relative to a point on the edge of Sheldon Glacier (indicated in Fig. 1), included are stations 3-7.

the shelf will dilute ${ }^{231} \mathrm{~Pa}$ in sediments, leading to low ${ }^{227}$ Ac release. The ${ }^{227}$ Ac activities also suggest negligible inputs from coastal or land sources. However, without depth profile samples it is not possible here to quantify ${ }^{227}$ Ac from terrigenous sources versus UCDW. We suggest that future work assessing ${ }^{227} \mathrm{Ac}$ activities in deeper waters could aid in constraining the extent of UCDW incursions integrated over several years.

\section{Mixing rates within Ryder Bay}

Short-lived $\mathrm{Ra}$ isotopes have previously been used to estimate horizontal eddy diffusivity in other Southern Ocean waters (Charette et al. 2007). If the distribution of Ra can be described by diffusion, as opposed to advection, then a one-dimensional diffusion model can be used to calculate eddy diffusion coefficients $\left(k_{h}\right)$ along an onshoreoffshore transect, as developed by Moore (2000a). In this case, activity can be expressed according to the equation:

$$
A_{x}=A_{o} \cdot e^{-x \sqrt{\lambda / k_{h}}}
$$

where $A_{x}$ and $A_{o}$ are the activities at distance $x$ (from shore) and at the source $(x=0)$, respectively, and $\lambda$ is the decay constant. From this equation, if $\ln \left(A_{x}\right)$ is plotted versus distance $(x)$, the slope $(m)$ can be expressed as follows:

$$
m=\sqrt{\lambda / k_{h}} \text {. }
$$

Thus the decay constant and slope from the $\ln \left(A_{x}\right)$ versus distance plot can be used to calculate $k_{h}$ (Moore 2000a). This estimate of eddy diffusivity does not solely reflect eddy diffusion, and significant advection will result in a non-linear relationship, either concave (onshore advection) or convex (offshore) (see Dulaiova et al. 2009). Thus, provided the data display a reasonably linear fit, the $k_{h}$ can be considered an "effective" horizontal eddy diffusion coefficient giving an estimate of offshore mixing (Charette et al. 2007). For transects from South Cove into central Ryder Bay, the $k_{h}$ values determined for this study are $1.0 \mathrm{~m}^{2} \mathrm{~s}^{-1}$ for ${ }^{224} \mathrm{Ra}_{\mathrm{ex}}\left(0.64 \mathrm{~m}^{2} \mathrm{~s}^{-1}\right.$ if island stations are included) and $0.13 \mathrm{~m}^{2} \mathrm{~s}^{-1}$ for ${ }^{223} \mathrm{Ra}_{\mathrm{ex}}\left(0.31 \mathrm{~m}^{2} \mathrm{~s}^{-1}\right.$ if island stations are included; Fig. 4).

As Ryder Bay is enclosed on three sides, a simple diffusion model may be inadequate to represent the pattern of circulation in Ryder Bay, and the data here are unlikely to fulfil the assumption that activity decreases to zero at some distance. However, while there are significant potential caveats in the determination of $k_{h}$ here, the semi-enclosed nature of Ryder Bay should contribute to higher $\mathrm{Ra}$ activities in mid-bay stations than if the only $\mathrm{Ra}$ source was a point source (i.e. station 1), which would result in the calculated mixing rates being overestimates. As a result, the overall magnitude of mixing suggested here $\left(\leq 1.0 \mathrm{~m}^{2} \mathrm{~s}^{-1}\right)$ is worthy of note.

This range of eddy coefficients from the islands transect $\left(0.13-1.0 \mathrm{~m}^{2} \mathrm{~s}^{-1}\right)$ is much lower than the $6.6-39 \mathrm{~m}^{2} \mathrm{~s}^{-1}$ range estimated by Charette et al. (2007). Both of these $k_{h}$ estimates are extremely low in comparison to those estimated for other coastal regions (e.g. $360-420 \mathrm{~m}^{2} \mathrm{~s}^{-1}$ for the South Atlantic Bight; Moore 2000a) including the northern Antarctic Peninsula (596-63000 $\mathrm{m}^{2} \mathrm{~s}^{-1}$; Dulaiova et al. 2009). This strongly supports very slow diffusion from the margins to the centre of the bay, implying that mid-bay waters are sourced predominantly from more open ocean or 
deep waters, with very little influence from land-water exchange. Any sedimentary source of micronutrients (e.g. iron), would thus be expected to be very low in central Ryder Bay, and probably Marguerite Bay as well, and to occur via sediment-water interaction before the modified UCDW enters Ryder Bay. However, as noted above, ${ }^{228} \mathrm{Ra}$ is higher than in open ocean surface waters, and the longer $t_{1 / 2}$ reflects the longer timescale of the postulated sediment interaction. This interaction is probably on the order of several months to several years before the water enters Ryder Bay, while the very low short-lived $\mathrm{Ra}$ isotope activities reflect little or no input on the scale of one week to one month.

In addition to mixing rates, short-lived Ra measurements can also be used to estimate the length of time a water parcel has been isolated from the Ra source. Ratios of ${ }^{224} \mathrm{Ra}_{\mathrm{ex}}:{ }^{228} \mathrm{Ra}$ were used to estimate ages in mid-bay samples, following Moore (2000b) and Dulaiova et al. (2009). Taking the activity ratio at station 1 as the source end-member, stations 3-5 display Ra ages of 13,14 and 18 days, respectively. The very low rates of horizontal transport determined above are consistent with these age estimates, as studies in other regions have found younger ages for water much farther offshore (e.g. Ra age of approximately seven days up to $150 \mathrm{~km}$ offshore; Dulaiova et al. 2009).

Similar evaluation of $k_{h}$ was performed for the glacier transect. As Sheldon Glacier terminates over a large area at the northern end of Ryder Bay, distances were measured from an arbitrarily chosen point on the nearest ice-edge (shown in Fig. 1). As the calculation for $k_{h}$ depends on the slope of the plot versus $x$, only relative distances are taken into account, such that the absolute distance between source and sample does not affect the estimated $k_{h}$. Due to the two values bdl for ${ }^{223} \mathrm{Ra}_{\mathrm{ex}}$, only ${ }^{224} \mathrm{Ra}_{\mathrm{ex}}$ activity was used to assess $k_{h}$, giving an estimate of $18 \mathrm{~m}^{2} \mathrm{~s}^{-1}$ for mixing between the area around Sheldon Glacier and mid-Ryder Bay (Fig. 4). In agreement, ages derived using station 7 ratios as a source ( 0.5 and 8 days, for stations 6 and 5, respectively), are considerably lower than those calculated for sediment sources. That the $k_{h}$ estimate for glacial mixing is an order of magnitude greater than the estimates for the islands transect may reflect the nature of the underlying dispersive processes. If the enrichment signal derives from glacial meltwater as postulated, this would be present in a shallow freshwater lens at the surface. This water could be differentially affected by processes that induce horizontal mixing at the surface (potentially atmospherically-forced; i.e. wind, inertial currents etc.), in addition to overall horizontal mixing occurring in the water column. This may potentially account for the faster effective horizontal diffusivity of a glacier-derived signal compared to that from sediments.

Previous studies have combined estimates of $k_{h}$ with ${ }^{228} \mathrm{Ra}$ gradients to estimate offshore fluxes of ${ }^{228} \mathrm{Ra}$ (see Dulaiova et al. 2009). Following this approach, we used the islands transect stations, plus the RaTS site, to assess the gradient of ${ }^{228} \mathrm{Ra}$ away from shore in Ryder Bay, which gave a slope of $0.61 \pm 2.0 \mathrm{dpm} \mathrm{m}^{-3} \mathrm{~km}^{-1}$. There was considerable scatter in the data and the $r^{2}$ value for the regression $\left({ }^{228} \mathrm{Ra} v \mathrm{vs}\right.$ distance to nearest land) was very low (0.18). To obtain an upper estimate for ${ }^{228} \mathrm{Ra}$ flux, we used an upper limit of the ${ }^{228} \mathrm{Ra}$-gradient slope plus error $\left(2.6 \mathrm{dpm} \mathrm{m}^{-3} \mathrm{~km}^{-1}\right)$ multiplied by the highest value estimated for $k_{h}\left(1.0 \mathrm{~m}^{-2} \mathrm{~s}^{-1}\right.$; from ${ }^{224} \mathrm{Ra}_{\text {ex }}$ data along this transect), which gives a ${ }^{228} \mathrm{Ra}$ flux of $230 \mathrm{dpm} \mathrm{m} \mathrm{m}^{-2} \mathrm{~d}^{-1}$. While there is a high degree of uncertainty in this calculation, reflected in the standard error of the slope, the magnitude of this upper ${ }^{228} \mathrm{Ra}$ flux estimate is relatively low compared to other Southern Ocean locations. For example, the ${ }^{228} \mathrm{Ra}$ flux calculated by Charette et al. (2007) around Iles Crozet is $1630-9660 \mathrm{dpm} \mathrm{m}^{-2} \mathrm{~d}^{-1}$. The estimate for Livingston Island (South Shetland Islands) is $31900 \mathrm{dpm} \mathrm{m}^{-2} \mathrm{~d}^{-1}$, although the estimate for Elephant Island (South Shetland Islands) is very low $\left(15.8 \mathrm{dpm} \mathrm{m}^{-2} \mathrm{~d}^{-1}\right.$, Dulaiova et al. 2009). We suggest that location plays a large role in determining fluxes: low values are found in Ryder Bay (coastal Antarctic), high values near Iles Crozet (sub-Antarctic islands), and the large range of the Dulaiova et al. (2009) study at the northern tip of the western Antarctic Peninsula may include regions with both Antarctic and subAntarctic characteristics. Our analysis shows that land-ocean inputs are low in the Antarctic environment, and as such ice-ocean fluxes may dominate in these regions.

Analysis by Cochran \& Krishnaswami (1980) determined that bioturbation is the dominant process contributing to sedimentary ${ }^{228} \mathrm{Ra}$ flux, and as such our very low upper estimate of ${ }^{228} \mathrm{Ra}$ flux may indicate a relatively low amount of bioturbation in Ryder Bay and/or the sediments underlying the path of water entering Ryder Bay. Marine surveys around Rothera Research Station report high abundances of benthic organisms and largely bare rock substrates (Smale et al. 2008). Thus, it is more probable that the low Ryder Bay fluxes reflect comparatively low amounts of sediments in shallow (mixed-layer) waters, as opposed to scarcity of bioturbating organisms. Frequent scouring by icebergs, as is the case in shallow waters of Ryder Bay (Smale et al. 2008), or the very steep sides of the bay, may also contribute to low amounts of sediment.

\section{Conclusions}

Here we present short-lived Ra isotope activities in a shallow embayment on the western Antarctic Peninsula, and the activities of their progenitor isotopes. These measurements are the most southerly to date. The activities of both ${ }^{223} \mathrm{Ra}_{\mathrm{ex}}$ and ${ }^{224} \mathrm{Ra}_{\text {ex }}$ were low compared to other coastal Southern Ocean locations, and extremely low compared to those reported for low latitude regions.

Waters near Sheldon Glacier show a clear enrichment signal in ${ }^{223} \mathrm{Ra}_{\mathrm{ex}},{ }^{224} \mathrm{Ra}_{\mathrm{ex}}$, and ${ }^{228} \mathrm{Ra}$. Although seawatersediment interaction underneath the ice is also a potential source for this enrichment, material entrained within the ice itself is a more likely source, as other studies have found. 
The mid-bay activities resemble relatively open water, indicating very little interaction with sediment-water or land-water interfaces, although elevated ${ }^{228} \mathrm{Ra}$ indicates some continental shelf influence over timescales on the order of several months to years. The high activities of ${ }^{227} \mathrm{Ac}$ reflect that the ultimate source for Ryder Bay surface waters is UCDW, which is known to intrude onto the WAP shelf episodically.

Horizontal mixing rates between mid-bay and shore waters are significantly slower than those reported for other coastal areas, consistent with relatively high Ra ages for such an environment. Given the slow mixing rates and extremely low short-lived $\mathrm{Ra}$ activities for a relatively shallow coastal environment, sediment interaction and coastal runoff are therefore not likely to be a major source of micronutrients to Ryder Bay. The mixing rate estimate for glacial to mid-bay waters, however, is more than an order of magnitude greater than those for nonglacial samples, indicating that glacially influenced waters represent a more dispersive source of terrestrial material (and any associated micronutrients) in coastal areas.

\section{Acknowledgements}

The authors would like to thank the Rothera Research Station marine staff, in particular Danny Edmunds, for help with sample collection, and the British Antarctic Survey for logistical support. Jan Scholten at the International Atomic Energy Agency in Monaco kindly provided standards, and helpful discussion regarding methodology. The editor (L. Padman) and two anonymous reviewers provided valuable comments to improve the manuscript. This work was supported by an Antarctic Science Bursary, Collaborative Gearing Scheme funding (through the National Environment Research Council, UK), the British Council-EGIDE ALLIANCE/Franco-British Research Partnership Programme, an NSERC scholarship and the University of Edinburgh.

\section{References}

Charette, M.A., Buesseler, K.O. \& Andrews, J.E. 2001. Utility of radium isotopes for evaluating the input and transport groundwater-derived nitrogen to a Cape Cod estuary. Limnology and Oceanography, 46, 465-470.

Charette, M.A., Gonneea, M.E., Morris, P.J., Statham, P., Fones, G., Planquette, H., Salter, I. \& Garabato, A.N. 2007. Radium isotopes as tracers of iron sources fuelling a Southern Ocean phytoplankton bloom. Deep-Sea Research II, 54, 1989-1998.

Clarke, A., Meredith, M.P., Wallace, M.I., Brandon, M.A. \& Thomas, D.N. 2008. Seasonal and interannual variability in temperature, chlorophyll and macronutrients in northern Marguerite Bay, Antarctica. Deep-Sea Research II, 55, 1988-2006.

Cochran, J.K. \& Krishnaswami, S. 1980. Radium, thorium, uranium and ${ }^{210} \mathrm{~Pb}$ in deep-sea sediments and sediment pore waters from the north equatorial Pacific. American Journal of Science, 280, 849-889.

Cook, A.J., Fox, A.J., Vaughan, D.G. \& Ferrigno, J.G. 2005. Retreating glacier fronts on the Antarctic Peninsula over the past half-century. Science, 308, 541-544.
Dimova, N., Dulaiova, H., Kim, G. \& Burnett, W.C. 2008. Uncertainties in the preparation of ${ }^{224} \mathrm{Ra} \mathrm{Mn}$ fiber standards. Marine Chemistry, 109, 220-225.

Dulaiova, H., Ardelan, M.V., Henderson, P.B. \& Charette, M.A. 2009. Shelf-derived iron inputs drive biological productivity in the southern Drake Passage. Global Biogeochemical Cycles, 10.1029/2008GB003406.

Garcia-Solsona, E., Garcia-Orellana, J., Masqué, P. \& Dulaiova, H. 2008. Uncertainties associated with ${ }^{223} \mathrm{Ra}$ and ${ }^{224} \mathrm{Ra}$ measurements in water via a Delayed Coincidence Counter (RaDeCC). Marine Chemistry, 109, 198-219.

Geibert, W. \& VöGE, I. 2008. Progress in the determination of ${ }^{227}$ Ac in sea water. Marine Chemistry, 109, 238-249.

Geibert, W., Rutgers van der Loeff, M.M., Hanfland, C. \& Dauelsberg, H.-J. 2002. Actinium-227 as a deep-sea tracer: sources, distribution and applications. Earth and Planetary Science Letters, 198, 147-165.

HaNFLAND, C. 2002. Radium-226 and radium-228 in the Atlantic sector of the Southern Ocean. $\mathrm{PhD}$ thesis, University of Bremen, $135 \mathrm{pp}$.

Hoffmann, L.J., Peeken, I. \& Lochte, K. 2008. Iron, silicate, and light co-limitation of three Southern Ocean diatom species. Polar Biology, 31, 1067-1080.

Howard, S.L., Hyatt, J. \& Padman, L. 2004. Mixing in the pycnocline over the western Antarctic Peninsula shelf during Southern Ocean GLOBEC. Deep-Sea Research II, 51, 1965-1979.

Jeandel, C., Peucker-Ehrenbrink, B., Jones, M.T., Pearce, C.R., Oelkers, E.H., Godderis, Y., Lacan, F., Aumont, O. \& Arsouze, T. 2011. Ocean margins: the missing term in oceanic element budgets? Eos Transactions, 92, 217-224.

KLINCK, J. 1998. Heat and salt changes on the continental shelf west of the Antarctic Peninsula between January 1993 and January 1994. Journal of Geophysical Research, 103, 7617-7636.

Martinson, D.G., Stammerjohn, S.E., Iannuzzi, R.A., Smith, R.C. \& Vernet, M. 2008. Western Antarctic Peninsula physical oceanography and spatio-temporal variability. Deep-Sea Research II, 55, 1964-1987.

Meredith, M.P. \& King, J.C. 2005. Rapid climate change in the ocean west of the Antarctic Peninsula during the second half of the 20th century. Geophysical Research Letters, 10.1029/2005GL024042.

Meredith, M.P., Venables, H.J., Clarke, A., Ducklow, H.J., Erickson, M., Leng, M.J., Lenaerts, J.T.M. \& van den Broeke, M.R. In press. The freshwater system west of the Antarctic Peninsula: spatial and temporal changes. Journal of Climate.

Meredith, M.P., Wallace, M.I., Stammerjohn, S.E., Renfrew, I.A., Clarke, A., Venables, H.J., Shoosmith, D.R., Souster, T. \& Leng, M.J. 2010. Changes in the freshwater composition of the upper ocean west of the Antarctic Peninsula during the first decade of the 21st century. Progress in Oceanography, 87, 127-143.

Moffat, C., Owens, B. \& Beardsley, R.C. 2009. On the characteristics of Circumpolar Deep Water intrusions to the west Antarctic Peninsula continental shelf. Journal of Geophysical Research, 10.1029/2008JC004955.

Moffat, C., Beardsley, R.C., Owens, B. \& van Lipzig, N. 2008. A first description of the Antarctic Peninsula coastal current. Deep-Sea Research II, 55, 277-293.

Montes-Hugo, M., Doney, S.C., Ducklow, H.W., Fraser, W., Martinson, D., StAMmERJoHn, S.E. \& SCHOFIELD, O. 2009. Recent changes in phytoplankton communities associated with rapid regional climate change along the western Antarctic Peninsula. Science, 323, 1470-1473.

MoORE, W.S. 2000a. Determining coastal mixing rates using radium isotopes. Continental Shelf Research, 20, 1993-2007.

Moore, W.S. 2000b. Ages of continental shelf waters determined from ${ }^{223} \mathrm{Ra}$ and ${ }^{224} \mathrm{Ra}$. Journal of Geophysical Research, 105, $22117-22122$.

Moore, W.S. 2008. Fifteen years experience in measuring ${ }^{224} \mathrm{Ra}$ and ${ }^{223} \mathrm{Ra}$ by delayed-coincidence counting. Marine Chemistry, 109, 188-197.

Moore, W.S. \& ARnold, R. 1996. Measurement of ${ }^{223} \mathrm{Ra}$ and ${ }^{224} \mathrm{Ra}$ in coastal waters using a delayed coincidence counter. Journal of Geophysical Research, 101, 1321-1329. 
Pritchard, H.D., Ligtenberg, S.R.M., Fricker, H.A., Vaughan, D.G., van den Broeke, M.R. \& Padman, L. 2012. Antarctic ice sheet loss driven by basal melting of ice shelves. Nature, 484, 502-505.

Raiswell, R. 2011. Iceberg-hosted nanoparticulate Fe in the Southern Ocean mineralogy, origin, dissolution kinetics and source of bioavailable Fe. Deep-Sea Research II, 58, 1364-1375.

Rutgers VAN DER LoefF, M.M. 1994. ${ }^{228} \mathrm{Ra}$ and ${ }^{228} \mathrm{Th}$ in the Weddell Sea. In Johannessen, O.M., Muench, R.D. \& Overland, J.E., eds. The polar oceans and their role in shaping the global environment. The Nansen centennial volume. Geophysical Monograph Series, 85, 177-186.

Scholten, J.C., Pham, M.K., Blinova, O., Charette, M.A., Dulaiova, H. \& Eriksson, M. 2010. Preparation of Mn-fiber standards for the efficiency calibration of the delayed coincidence counting system (RaDeCC). Marine Chemistry, 121, 206-214.

Shaw, T.J. \& Moore, W.S. 2002. Analysis of ${ }^{227}$ Ac in seawater by delayed coincidence counting. Marine Chemistry, 78, 197-203.

Shaw, T.J., Raiswell, R., Hexel, C.R., Vu, H.P., Moore, W.S., Dudgeon, R. \& Sмith, K.L. 2011. Input, composition, and potential impact of terrigenous material from free-drifting icebergs in the Weddell Sea. Deep-Sea Research II, 58, 1376-1383.

Smale, D.A., Barnes, D.K.A., Fraser, K.P.P. \& Peck, L.S. 2008. Benthic community response to iceberg scouring at an intensely disturbed shallow water site at Adelaide Island, Antarctica. Marine Ecology Progress Series, 355, 85-94.
Stammerjohn, S.E., Martinson, D.G., Smith, R.C., Yuan, X. \& Rind, D. 2008. Trends in Antarctic annual sea ice retreat and advance and their relation to El Niño-Southern Oscillation and Southern Annular Mode variability. Journal of Geophysical Research, 10.1029/2007JC004269.

Van Beek, P., Souhaut, M. \& Reyss, J.-L. 2010. Measuring the radium quartet $\left({ }^{226} \mathrm{Ra},{ }^{228} \mathrm{Ra},{ }^{224} \mathrm{Ra},{ }^{223} \mathrm{Ra}\right)$ in water samples using gamma spectrometry. Journal of Environmental Radioactivity, 101, 521-529.

Van Beek, P., Bourquin, M., Reyss, J-.L., Souhaut, M., Charette, M.A. \& JEANDEL, C. 2008. Radium isotopes to investigate the water mass pathways on the Kerguelen Plateau (Southern Ocean). Deep-Sea Research II, 55, 622-637.

Van Beek, P., Souhaut, M., Lansard, B., Bourquin, M., Reyss, J-L., Jean, P. \& von BALlmoos, P. In press. LAFARA: A new underground laboratory in the French Pyrénées for ultra low-level gamma-ray spectrometry. Journal of Environmental Radioactivity.

Vaughan, D.G., Marshall, G.J., Connolley, W.M., Parkinson, C., Mulvaney, R., Hodgson, D.A., King, J.C., Pudsey, C.J. \& Turner, J. 2003. Recent rapid regional climate warming on the Antarctic Peninsula. Climatic Change, 60, 243-274.

Venables, H.J., Clarke, A. \& Meredith, M.P. In press. Wintertime controls on summer stratification and productivity at the western Antarctic Peninsula. Limnology and Oceanography.

Wallace, M.I., Meredith, M.P., Brandon, M.A., Sherwin, T.J., Dale, A. \& Clarke, A. 2008. On the characteristics of internal tides and coastal upwelling behaviour in Marguerite Bay, west Antarctic Peninsula. Deep-Sea Research II, 55, 2023-2040. 